\title{
Living Arrangement of Older Persons in Finland
}

\author{
Jarl Lindgren, D.Sc. (Agr. \& For.)
}

\section{Abstract}

This article presents some of the main results from the Finnish report of the project of the Dynamics of Population Aging in the ECE-countries, a project carried out by the Population Activities Unit of the Economic Commission for Europe. Living arrangement, income and household condition of senior citizens aged 60 and over are discussed. Living arrangement are studied in private household, according gender, marital status, and number of generations and kin present in the household. The economic situation is examined by economic activities, income size and income sources. Further, dwelling size and household amenities are reported.

The Finnish report and this article illustrate the situation in Finland during the late 1980 s and the early 1990s.

Keywords: Living arrangement, income, housing condition, aged population, Finland

\section{Introduction}

The demographic trend toward an aging population is already a reality in the highly industrialized Europe and North America and is gradually extending to the Third World. When the large cohorts of the post-World War baby boom retire, a demographic condition that has never been experienced will emerge: unprecedented proportions of the population will be over 60 years of age. While Finland was one of the last European countries to pass the demographic transition, it will be one of the first to face the population aging in full scale. This is due, largely in part, to those age groups born immediately after the Second World War. Within ten to twenty years these large age groups will reach the pensionable age and the proportion of the senior citizens will grow to nearly twice as large as it is today.

Simultaneously with this demographic development, industrialized societies have experienced social, cultural and economic changes. For instance, a prevailing collective 
pattern of behavior has gradually transformed into a more individualistic. Consequently, the post-war period in Europe, North America and a number of other countries has experienced substantial changes in the living arrangement of older people. This has been characterized by an increasing proportion of older individuals living alone and a decrease in the proportion of elderly living in complex households with kin other than members of the nuclear family. Much of this shift in living arrangements has occurred in the relatively recent past, particularly since the 1960 s.

This article presents some of the main results from the Finnish report of the project The Dynamics of Population Aging in the ECE-countries. The project is carried out by the Population Activities Unit of the Economic Commission for Europe (ECE) ${ }^{1}$. Within the ECE-countries, population aging is an important issue. Since detailed information on the elderly population does not exist for the ECE-region, the goal of the project is to assess the social, demographic and economic conditions of the elderly population living in ECE-member states. The Finnish part of the project uses data from microcensus samples based on the 1990 census, which is entirely register-based and is supplemented with information from earlier studies.

In addition to providing an overview of the demographic and economic background, the Finnish report includes information on living arrangement and economic situation of persons aged 50 and over. Living arrangements are studied in private households and include household size, generations, and kin represented in the household. The extent of institutionalization is also considered. The economic situation is examined by economic activity and income sources. Further, dwelling size, household amenities, and disability status are reported. These aspects are examined according to gender, marital status, age and number of generations present in the household. In this article, I discuss living arrangement, income, and housing conditions of senior citizens aged 60 and over in Finland.

\section{Living arrangement}

The female life expectancy is approximately eight years longer than that of men. As a consequence of this difference, the pattern of living arrangements vary by age and gender. Aged men live together with some other person more often than women. Among women, on the contrary, living alone is more common and increases with age much more than among men. While about one third of the women aged 65-69 live alone, this proportion grows to almost 75 percent among those aged 85 and over. The corresponding figures among men change from 20 percent to 40 percent, respectively. Hence, the proportion of elderly living together with some other person diminishes with age, more 
significantly so for women than for men (Table 1). According to a 1994 survey, women living alone are often characterized as town-dwellers, former blue- or white-collar workers in poor physical health, and never married or childless (Melkas 1997). On the contrary, men form a more heterogeneous group, residing in countrysides as well as in towns while about half of them have worked as manual workers.

A small percentage of the senior citizens live within institutionalized settings that include homes for the aged, nursing homes, hospitals and mental institutions. Clearly, the proportion grows with age and is highest in the oldest age group. Among those aged 85 and over, one fifth of females and 13 percent of males live in institutions. Past economic growth has lead to improved social security benefits for the elderly such as home care and home nursing, housing allowances, and a universal pension system. This, in turn, has resulted in greater economic independence and residential autonomy for a growing proportion of older persons. The growth in the number of private households of senior citizens aged 55 and over reflect these changes (Sailas 1994). This increase, of 55 percent between 1960 to 1990, has been most significant among both the youngest and oldest cohorts of senior citizens. The primary reason why we see this change among the oldest cohort is that elderly men and women mostly prefer to live alone or with some other person until they are no longer able to do so.

Table 1. The living arrangement of persons aged 60 and over in 1990, \%

$\begin{array}{lcccc}\text { Males } & \begin{array}{c}\text { Living } \\ \text { alone }\end{array} & \begin{array}{c}\text { Living with } \\ \text { other persons }\end{array} & \text { Institutionalized } & \\ 60-64 & 16.2 & 83.1 & 0.7 & 100 \\ 65-69 & 16.8 & 82.1 & 1.1 & 100 \\ 70-74 & 18.2 & 80.3 & 1.5 & 100 \\ 75-79 & 23.4 & 73.8 & 2.8 & 100 \\ 80-84 & 30.1 & 64.2 & 5.7 & 100 \\ 85+ & 38.2 & 48.3 & 13.5 & 100 \\ \text { Total } & 19.5 & 78.5 & 2.0 & 100 \\ \text { Females } & & & & \\ 60-64 & 28.6 & 70.9 & 0.5 & 100 \\ 65-69 & 38.3 & 60.9 & 0.8 & 100 \\ 70-74 & 49.0 & 49.4 & 1.6 & 100 \\ 75-79 & 57.6 & 38.4 & 4.0 & 100 \\ 80-84 & 61.7 & 29.3 & 8.9 & 100 \\ 85+ & 56.7 & 22.2 & 21.2 & 100 \\ \text { Total } & 45.0 & 51.3 & 3.7 & 100\end{array}$


Overall, as age increases, the likelihood of living alone or with son or daughter increases for both men and women. However, there is variation by marital status, age, and gender. Most of the aged persons who coreside are married couples. In the youngest age group, aged $65-69$, two of ten live in a conventional family with children and a spouse, i.e. in a two-generation household. In the subsequent age groups, the number of childless couples increases. Nonetheless, among older individuals who coreside, more than 80 percent live as wife or husband, within a one-generation household (Figure 1).

Further, for those elderly who are widowed, divorced or separated, and never married, as age increases the tendency to live with someone else of the same generation decreases gradually. This trend is similar for both women and men. Among the widowed, 14 percent of men and women in the youngest age group, 60-65 years, reside in twogeneration families (i.e. parent and adult child). Approximately 10 percent of men and significantly less of women coreside with some other person of the same generation. This picture appears to be consistent over age.

Divorced and separated elderly demonstrate similar patterns as the widowed group. However, individuals from the two former groups tend to live together with a person of the same generation more often than those from the latter group. Further, divorced men live more often in such households than divorced women while never married men live more often together with someone belonging to the same generation than never married women.

Figure 1. Distribution of persons aged 60 and over according to generation present in the household, marital status, age and sex

Males

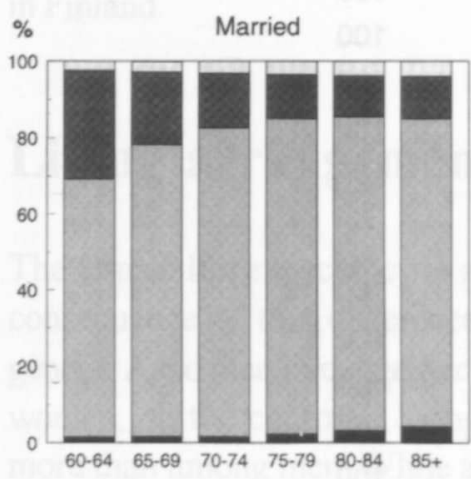

Females

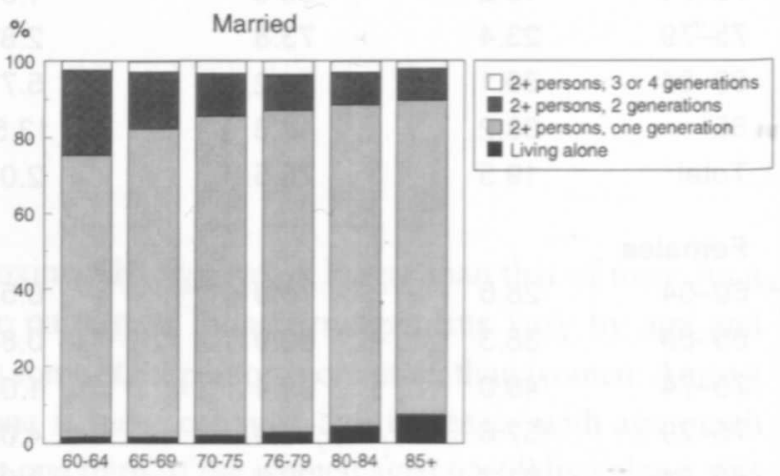


Males

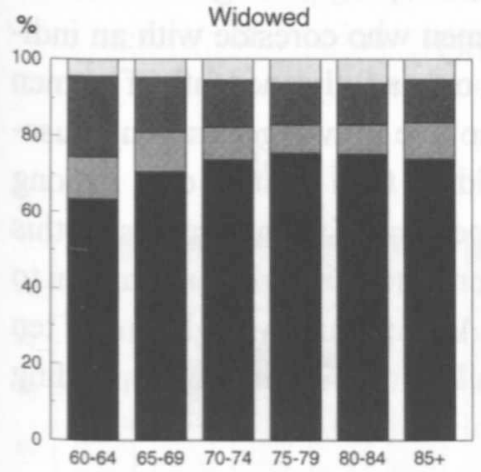

\section{Females}



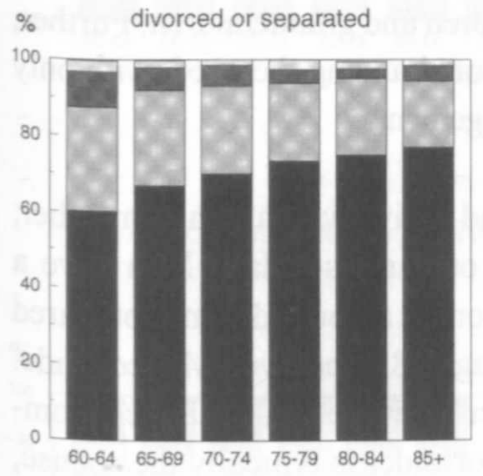
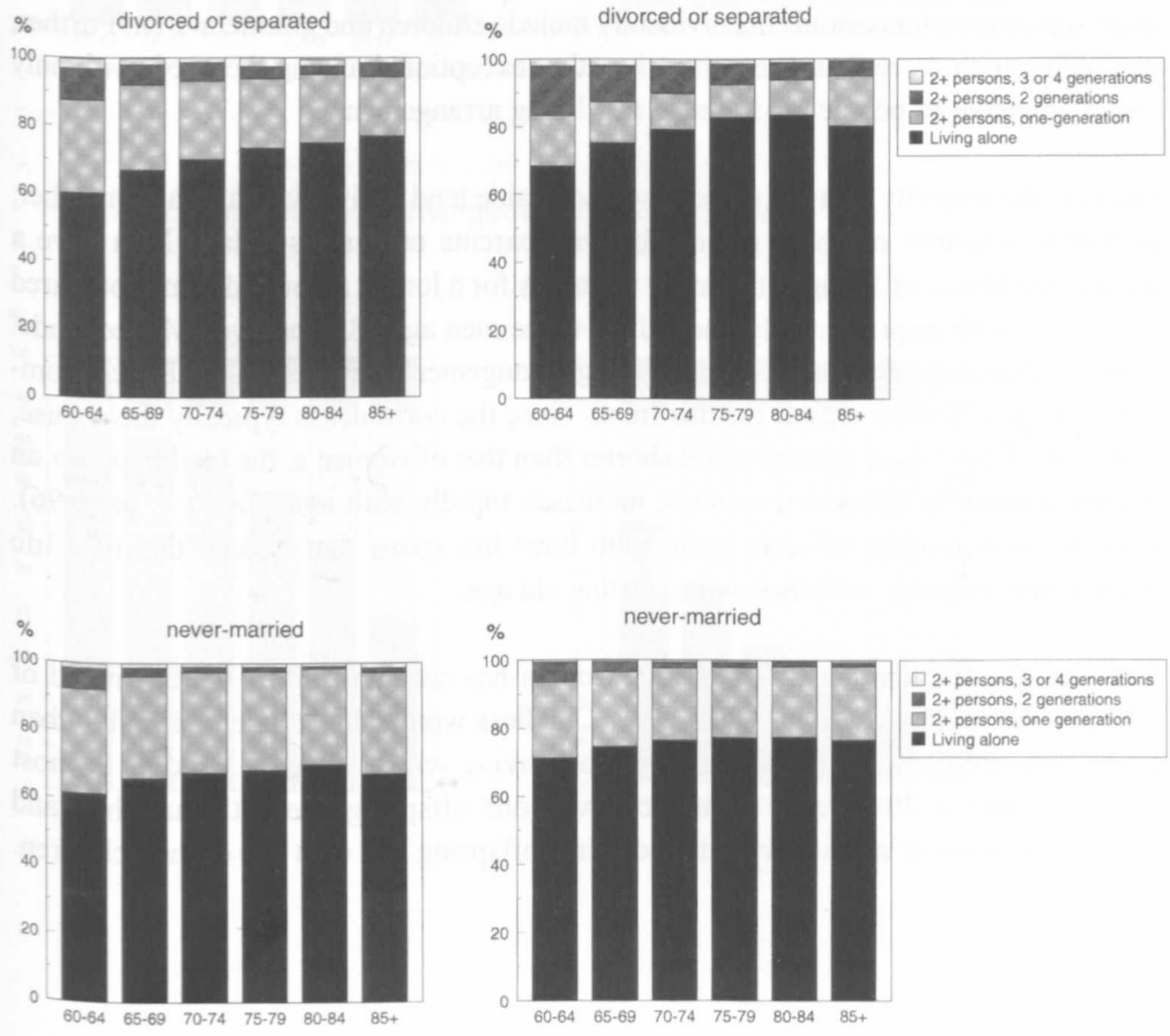
A closer examination of the relationship between type of residence and marital status demonstrates significant differences between the sexes (Figure 2). Living together with a spouse decreases gradually with age, significantly more rapidly among older women than among older men. While about one half of older men who coreside with an individual of the same generation still live with their wives, only a fully one tenth of women live in this type of household. Similarly, older men who live in two-generation households coreside more frequently with spouses and children than women do. Among those age 85 and over, 40 percent of men while only 5 percent of women represent this kind of living arrangement. On the contrary, among older women it is rather common to live in a two-generation household with only children. Approximately, eight out of ten women aged 80 and over live with one or several children while the corresponding proportion for men is only about four in ten.

Alternative living arrangements include living with other relatives, or in household with more than two generations. We find that there is a small portion of older persons, who live with other relatives; in two-generation households about ten percent for both sexes and in one-generation households still less. Also, while households of three or more generations are uncommon, about one fifth of older widowed people are found in multi-generation households that evidently include children and grandchildren. Further, coresiding with more than one person is rather exceptional among the aged, with only about 5 percent of people are found in this living arrangement.

Overall, the majority of aged persons who coreside tend to live with a family member, primarily a spouse or child, sometimes with parents or parents-in-law. Men have a greater likelihood of living with family members for a longer amount of time compared to women, with approximately one half of those men aged 85 and over who coreside. Among women, as age increases, this living arrangement becomes gradually less common. There is a clear reason for this trend: since the coresider is typically the spouse, and men's longevity is several years shorter than that of women's, the likelihood for an elderly woman to become a solitaire increases rapidly with age (Table 2, page 96). Only a small portion of older men, who have life spans that exceed the male life expectancy, coreside with their wives during old age.

Interestingly, the number of children a woman has seems to affect the likelihood of whether she will live alone at older ages. Childless women live alone more often than those with children. At the age of 85 , when living with a child or children is most common, almost 20 percent of mothers with one offspring live with that child and about 40 percent of mothers with two or three offspring live with one of their children. 
Figure 2. Distribution of aged persons living in one- and two-generation households, by household composition, age and sex

\section{One-generation households}
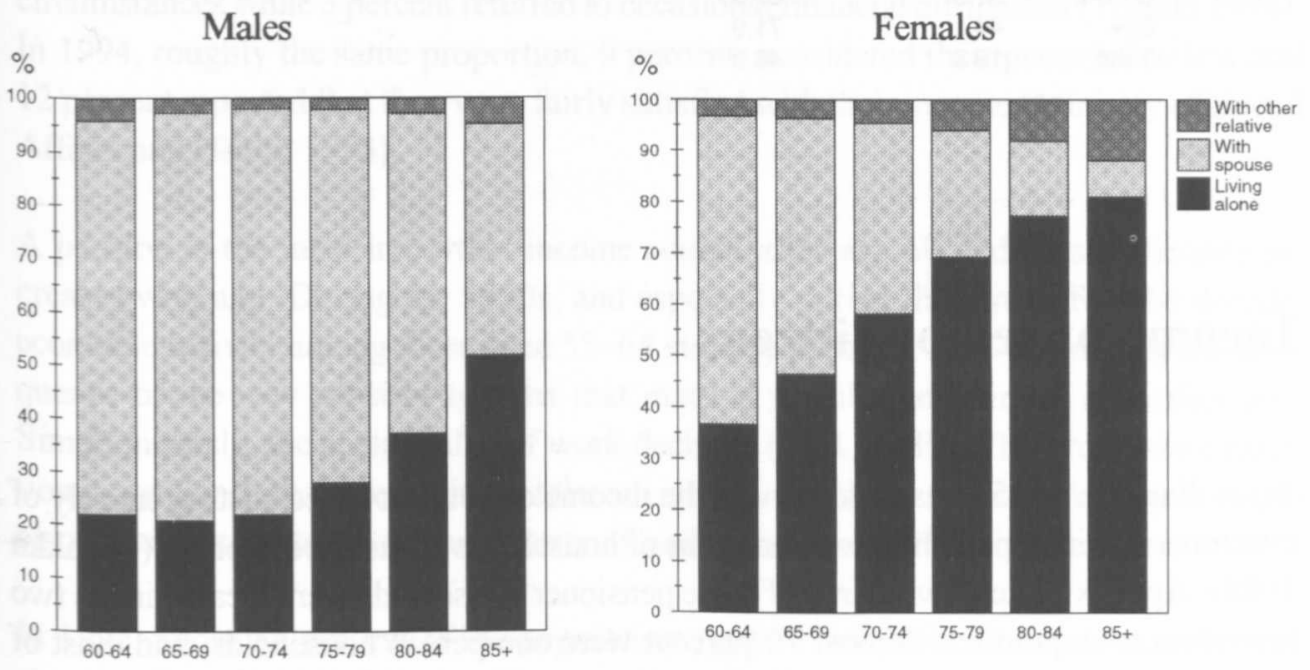

Two-generation households
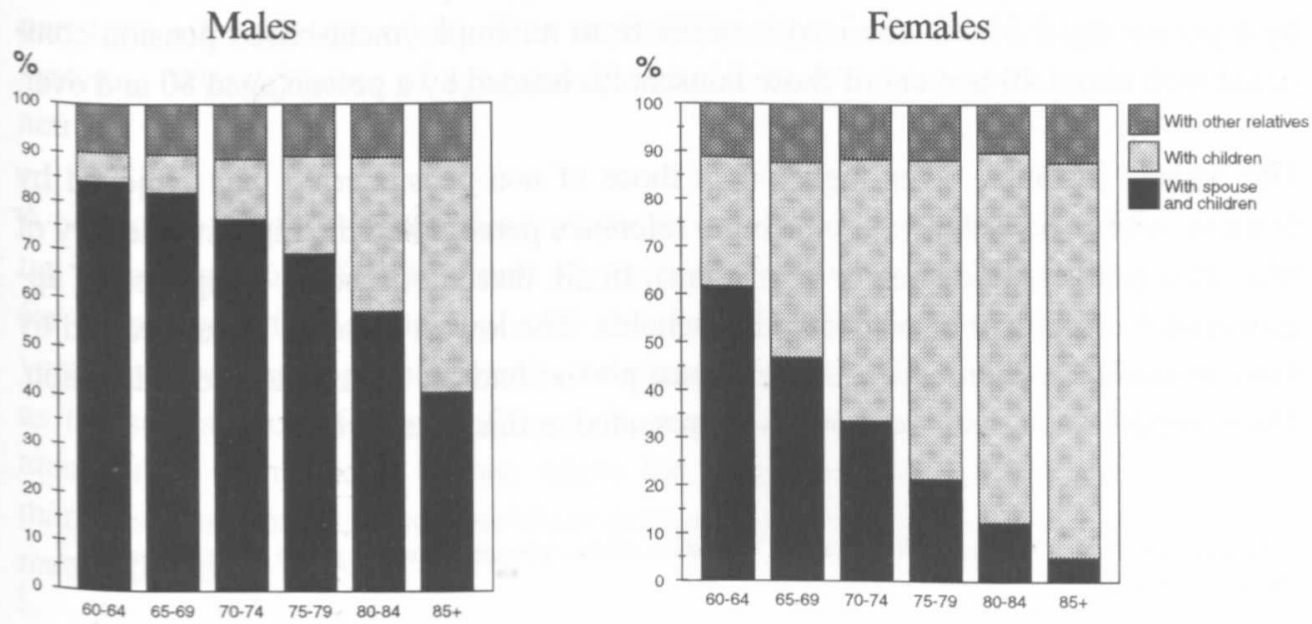
Table 2. The proportion of persons aged 60 and over living alone, by age and sex, $\%$

$\begin{array}{lcc} & \text { Males } & \text { Females } \\ 60-64 & 16.2 & 28.7 \\ 65-69 & 16.9 & 38.6 \\ 70-74 & 18.4 & 49.8 \\ 75-79 & 24.0 & 60.1 \\ 80-84 & 31.9 & 67.8 \\ 85+ & 44.1 & 71.9 \\ \text { Total } & 19.8 & 46.8\end{array}$

\section{Income of senior citizens}

According to a 1985 household survey, the income of households consisting entirely of pensioners was 20 percent lower than that of households without pensioners (Puhakka 1988). Approximately two thirds of these pensioner households were located in the two lowest income quintiles. Almost 70 percent were one-person households, and most of the remainder were two-person households. Further, pensioners aged 65-69 had the highest incomes - calculated in terms of consumption units ${ }^{2}$ - while those over the age 80 received the lowest. This difference may exist since the younger age group included more beneficiaries of the employment-based pension than the older group, who commonly received the smaller national pension ${ }^{3}$. Finally, 60 percent of households headed by a person aged $65-69$ obtained benefits from an employment-based pension compared with about 40 percent of those households headed by a person aged 80 and over.

The highest income - even higher than those of non-pensioners - was enjoyed by those pensioner households in which the reference person ${ }^{4}$ had the highest category of education (university degree or equivalent). In all, these households comprised of approximately 4 percent of pensioner households. The lowest incomes were received by those households from which the reference person had the lowest level of education. Those aged 80 and over were overly represented in this latter group.

\footnotetext{
${ }^{2}$ The consumption unit for one adult is 1 , and 0.7 for other adults. A household with e.g. two adults represent 1.7 consumption units.

${ }^{3}$ There are two main pension insurance systems in Finland: the national pension system and the employment-based pension system. The national pension system is aimed at providing the security of a minimum income for all pensioners. The employment-based pension was introduced in 1960, and the full amount, 60 percent of the salary, will be attainable in the beginning of this decade. Now, pensioners receive a partial employment-based pension depending on how many years they have had after 1960. When the employment-based pension is too small to garantee a minimum income it is completed with a national pension.
}

${ }^{4}$ The person who is considered mainly responsible for providing the earnings of the household. 
According to a 1994 household survey, the average disposable income in a one-person pensioner household, age under 75, indicated little variation by gender (Sailas 1994). However, among persons aged 75 and over, the mean female income was 10 percent lower than that for males. Further, although income decreased with age, in 1985 only 8 percent of those aged 65 and over reported being dissatisfied with their economic circumstances while 3 percent referred to occasional financial difficulties (Tennilä 1994). In 1994, roughly the same proportion, 9 percent, considered their pension too low and 12 percent reported that they were fairly satisfied with their income (Ministry of Social Affairs and Health 1994).

A pension is the most important income source after age 60 and its significance increases with age. During the 1980 s, and especially during the last half of the decade, economic activity among those aged 55-64 steadily declined. This was mainly a consequence of the new pension systems that made it possible to retire at an earlier age. Simultaneously, the social value of work declined (EVA, 1989). The progressive taxation system and the opportunity to take advantage of various free social services might also have contributed to the popularity of early retirement (EVA, 1989).

In 1995, about 85 percent of the population aged 60-65 years received some form of pension (Statistical Yearbook of Pensioners in Finland 1996). During the first half of the 1990s the mean age at retirement was about 58. According to the PAU-project, despite the fact that most persons aged 60-64 were pensioners, almost half of this age group were economically active. This was due to the fact that many pensioners in this age group continued to work while they received their pension, e.g. those who worked part-time after the age of 60 . This is perfectly legal in the Finnish old-age pension systems. After 65 years of age, almost none of these individuals were economically active.

A pension is the only source of income in one-person households for roughly six out of ten people aged 65-69 (58 percent of men and 61 percent of women). This is the case for 65 percent of older men aged 80 and over, and 80 percent of older women. Divorced and separated people constitute the largest percentages of people with a pension as the sole source of income (Figure 3, page 98). This appears more prominently among men than among women where the proportions are almost the same in all marital status groups. In two- and three-person households the proportions are approximately the same. 
Figure 3. Proportion of persons aged 60 and over in one person households with pension as the only source of income, by age, sex and marital status
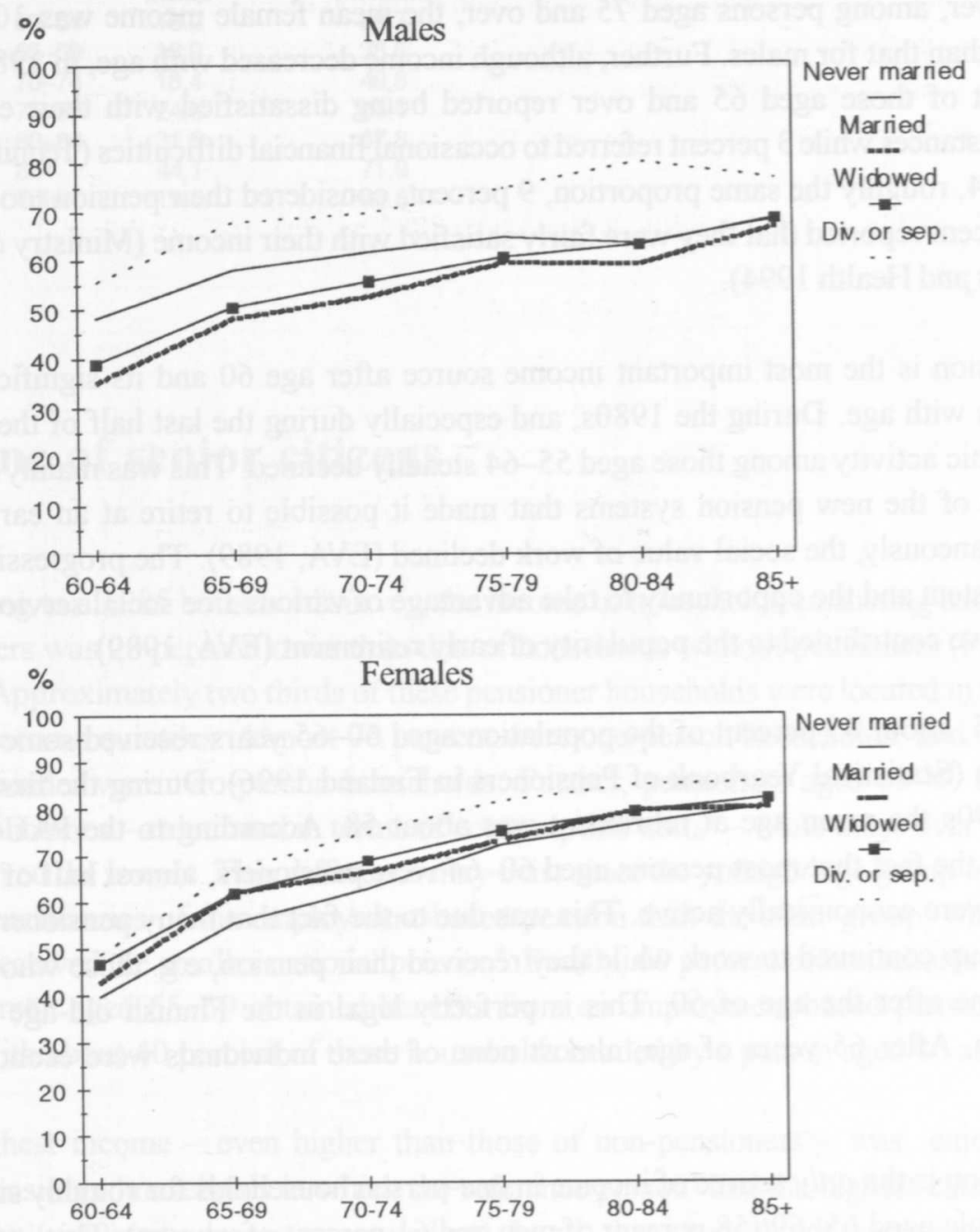

Although a pension is the most common single source of income among persons who have reached the general age of retirement ( 65 years of age), many pensioners have additional sources of income (Table 3). However, the income from these sources is rather small. According to the 1985 household survey, the additional income constituted approximately 9 percent of the total income of pensioner households, of those aged 55 and over. Most of this income was estimated income based on products produced or picked for own use, mostly farm and forest products (Puhakka, 1988). In 1990, among households of persons aged 65 or over, the income per consumption unit from other sources, i.e. property rental income and income from owner-occupied dwellings, was about ten percent of disposal income (Sailas 1994). This sort of income was almost nil in the two lowest quintiles to which the majority of senior citizens belong. For 
men, the proportions of income from other sources did not significantly vary by age. Thirty-fourty percent of the men in one-person households had some income from sources other than a pension and fifty-sixty in two- and three-person households, somewhat less in the two oldest yeargroups. In contrast, as age increased, women received less and less income from other sources; among women aged 80 and over, only somewhat less than 20 percent received income from other sources.

Table 3. Types of income sources of persons aged 60 and over, by age and sex, $\%$

\begin{tabular}{|c|c|c|c|c|c|c|c|c|c|}
\hline \multicolumn{10}{|c|}{ One person households } \\
\hline Males & None & Labour & \begin{tabular}{|c|} 
Enter- \\
prise
\end{tabular} & $\begin{array}{l}\text { Pen- } \\
\text { sion }\end{array}$ & \begin{tabular}{|l|} 
Labour + \\
pension
\end{tabular} & Other & \begin{tabular}{|c|} 
Un- \\
known
\end{tabular} & Total & Number \\
\hline $60-64$ & 0.6 & 5.6 & 2.4 & 48.2 & 6.8 & 36.0 & 0.4 & 100.0 & 19100 \\
\hline $65-69$ & 0.3 & 0.1 & 0.1 & 57.7 & 4.9 & 36.9 & 0.1 & 100.0 & 15444 \\
\hline $70-74$ & 0.1 & 0.0 & 0.0 & 59.6 & 2.8 & 37.3 & 0.0 & 100.0 & 11190 \\
\hline $75-79$ & 0.2 & 0.0 & 0.0 & 62.9 & 1.8 & 35.1 & 0.0 & 100.0 & 10875 \\
\hline $80-84$ & 0.2 & 0.0 & 0.0 & 63.9 & 1.5 & 34.1 & 0.0 & 100.0 & 8094 \\
\hline $85+$ & 0.2 & 0.0 & 0.0 & 68.6 & 1.0 & 30.3 & 0.0 & 100.0 & 4740 \\
\hline Total & & & & & & & & & 69443 \\
\hline \multicolumn{10}{|c|}{ Females } \\
\hline $60-64$ & 0.5 & 4.7 & 0.6 & 45.4 & 11.3 & 37.0 & 0.3 & 100.0 & 39135 \\
\hline $65-69$ & 0.1 & 0.1 & 0.0 & 61.4 & 5.1 & 33.2 & 0.0 & 100.0 & 50103 \\
\hline 70-74 & 0.1 & 0.0 & 0.0 & 68.5 & 2.5 & 28.9 & 0.0 & 100.0 & 51920 \\
\hline $75-79$ & 0.0 & 0.0 & 0.0 & 75.2 & 1.3 & 23.4 & 0.0 & 100.0 & 53482 \\
\hline $80-84$ & 0.1 & 0.0 & 0.0 & 79.0 & 0.6 & 20.2 & 0.0 & 100.0 & 39925 \\
\hline $85+$ & 0.2 & 0.0 & 0.0 & 81.9 & 0.4 & 17.5 & 0.0 & 100.0 & 22380 \\
\hline Total & & & & & & & & & 256945 \\
\hline
\end{tabular}

\begin{tabular}{|l|c|c|c|c|c|c|c|c|r|}
\hline \multicolumn{10}{|c|}{ Two- and three-person households } \\
\hline Males & None & Labour & $\begin{array}{c}\text { Enter- } \\
\text { prise }\end{array}$ & $\begin{array}{c}\text { Pen- } \\
\text { sion }\end{array}$ & $\begin{array}{l}\text { Labour+ } \\
\text { pension }\end{array}$ & Other & $\begin{array}{c}\text { Un- } \\
\text { known }\end{array}$ & Total & Number \\
\hline $60-64$ & 0.3 & 5.1 & 2.2 & 28.1 & 7.8 & 56.3 & 0.2 & 100.0 & 88271 \\
\hline $65-69$ & 0.1 & 0.1 & 0.1 & 38.1 & 6.2 & 55.4 & 0.0 & 100.0 & 70038 \\
\hline $70-74$ & 0.1 & 0.0 & 0.0 & 42.9 & 4.3 & 52.6 & 0.0 & 100.0 & 46125 \\
\hline $75-79$ & 0.0 & 0.0 & 0.0 & 39.5 & 2.3 & 58.1 & 0.0 & 100.0 & 39953 \\
\hline $80-84$ & 0.1 & 0.0 & 0.0 & 55.2 & 1.8 & 43.0 & 0.0 & 100.0 & 15858 \\
\hline $85+$ & 0.1 & 0.0 & 0.0 & 47.4 & 21.5 & 31.0 & 0.0 & 100.0 & 6808 \\
\hline Total & & & & & & & & & 267053 \\
\hline Females & \multicolumn{8}{|c|}{} \\
\hline $60-64$ & 2.3 & 6.0 & 2.7 & 40.3 & 8.6 & 39.7 & 0.5 & 100.0 & 89978 \\
\hline $65-69$ & 0.2 & 0.1 & 0.1 & 57.6 & 5.7 & 36.4 & 0.0 & 100.0 & 73870 \\
\hline $70-74$ & 0.1 & 0.0 & 0.0 & 64.2 & 5.7 & 30.1 & 0.0 & 100.0 & 48935 \\
\hline $75-79$ & 0.0 & 0.0 & 0.0 & 72.7 & 2.0 & 25.2 & 0.0 & 100.0 & 31530 \\
\hline $80-84$ & 0.1 & 0.0 & 0.0 & 77.4 & 1.0 & 21.5 & 0.0 & 100.0 & 16568 \\
\hline $85+$ & 0.2 & 0.0 & 0.0 & 82.0 & 0.5 & 17.2 & 0.0 & 100.0 & 7583 \\
\hline Total & & & & & & & & & 268464 \\
\hline
\end{tabular}




\section{Housing conditions}

Since the Second World War, the standard of housing has improved rapidly. While the average national dwelling size in 1990 was 31 square meters per person, for pensioners it was 43 . One explanation of the difference is that as retirement age approaches and household size diminishes, one's living space grows.

In 1990, approximately 80 percent of pensioners who lived alone and 87 percent of pensioners who were married resided in owner-occupied dwellings (Kärkkäinen 1994). However, half of the individuals approaching retirement age had a one-family house and the other half an owner-occupied apartment in an apartment building. When they get older, individuals tend to move from their family houses to apartment buildings with modern facilities, including elevators.

Those living alone have the largest average dwelling area per capita while households with three or more generations have the smallest. Only among one generation households, i.e. mainly married couples, do we find a decline in dwelling size with age (Figure 4). Even by marital status the tendency is the same: widowed people have the largest amount of space and married people have the least amount. In addition, the average dwelling size is somewhat larger for women than for men.

Figure 4. Average dwelling size per person among persons aged 60 and over, by age sex and a) number of generation present in the household, b) marital status.

a) Number of generation present in the household, Males

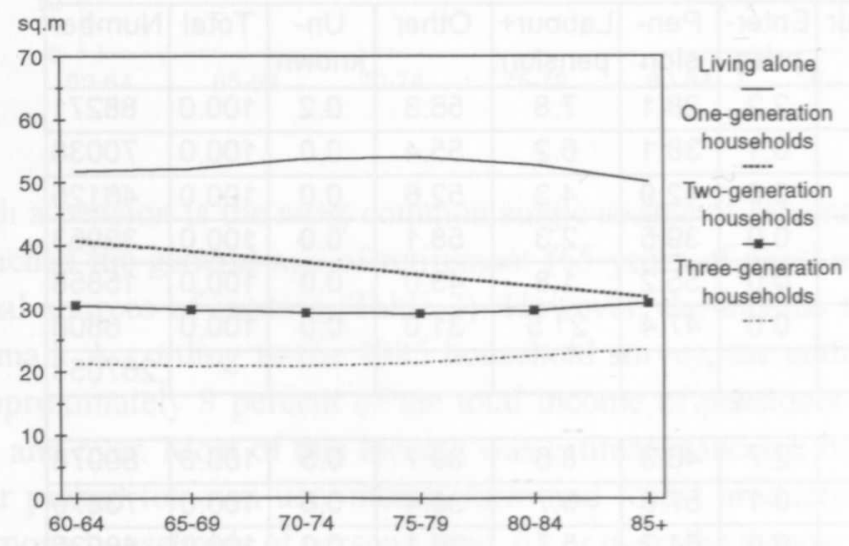


a) Number of generation present in the household, Females

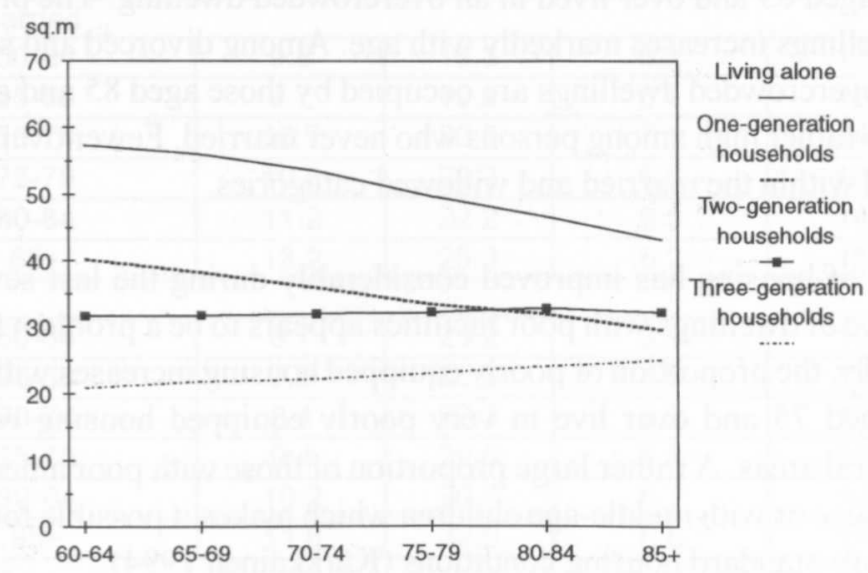

b) marital status, Males

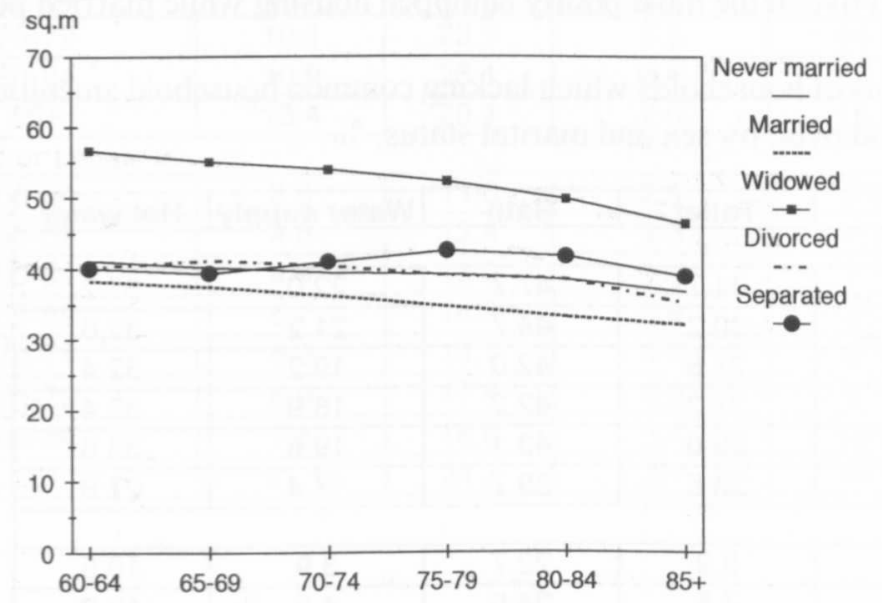

b) marital status, Females

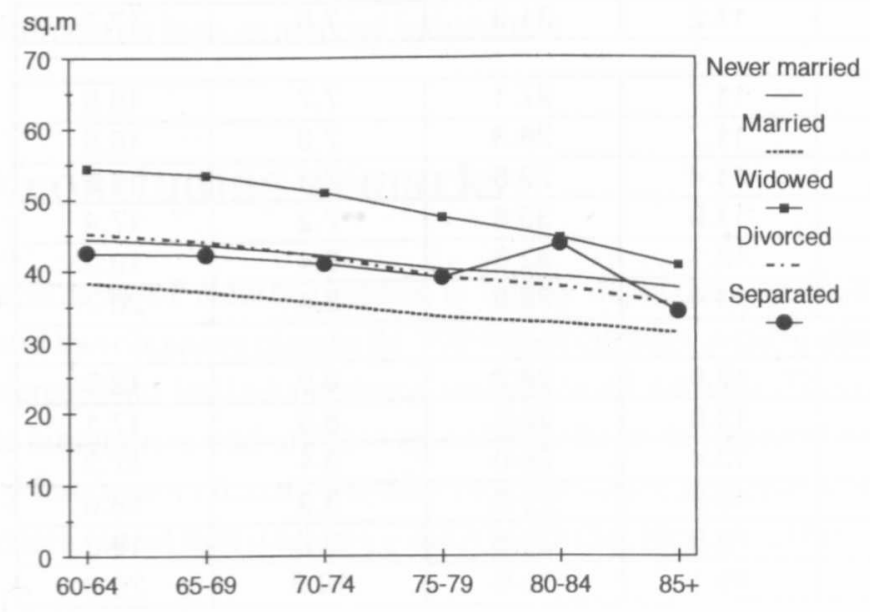


Although the majority of senior citizens live in spacious housing, in 1990 almost 20 percent of persons aged 65 and over lived in an overcrowded dwelling. The proportion of overcrowded dwellings increases markedly with age. Among divorced and separated people, half of the overcrowded dwellings are occupied by those aged 85 and over. The proportion was also rather high among persons who never married. Fewer overcrowded dwellings are found within the married and widowed categories.

While the standard of housing has improved considerably during the last several decades, the prevalence of dwellings with poor facilities appears to be a problem for many pensioners. Generally, the proportion of poorly equipped housing increases with age: 18 percent of those aged 75 and over live in very poorly equipped housing which are located mostly in rural areas. A rather large proportion of those with poor amenities are living with their spouse or with middle-age children which makes it possible for them to continue to live in sub-standard housing conditions (Kärkkäinen 1994).

The standard of amenities varies widely with marital status (Table 4). Men who have never been married live in the most poorly equipped housing while married people

Table 4. Proportions of households which lacking common household amenities among persons aged 60 and over, by sex and marital status, \%

\begin{tabular}{|c|c|c|c|c|}
\hline MALES & Toilet & Bath & Water supply & Hot water \\
\hline \multicolumn{5}{|l|}{ Never married } \\
\hline $60-64$ & 31.7 & 47.7 & 22.0 & 37.2 \\
\hline $65-69$ & 30.2 & 44.7 & 21.2 & 35.6 \\
\hline $70-74$ & 27.8 & 42.0 & 19.2 & 32.4 \\
\hline $75-79$ & 27.2 & 42.2 & 18.9 & 32.4 \\
\hline $80-84$ & 29.0 & 43.1 & 19.8 & 33.6 \\
\hline $85+$ & 23.5 & 39.7 & 17.4 & 27.8 \\
\hline \multicolumn{5}{|l|}{ Married } \\
\hline $60-64$ & 6.9 & 22.7 & 3.9 & 10.5 \\
\hline $65-69$ & 7.6 & 24.6 & 4.5 & 12.0 \\
\hline $70-74$ & 8.2 & 26.6 & 5.1 & 12.9 \\
\hline $75-79$ & 9.2 & 28.8 & 5.5 & 14.8 \\
\hline $80-84$ & 10.4 & 30.3 & 6.6 & 16.4 \\
\hline $85+$ & 11.2 & 31.3 & 7.5 & 17.7 \\
\hline \multicolumn{5}{|l|}{ Widowed } \\
\hline $60-64$ & 11.7 & 27.1 & 7.7 & 16.0 \\
\hline $65-69$ & 11.7 & 28.3 & 7.0 & 16.6 \\
\hline $70-74$ & 11.4 & 29.8 & 7.3 & 16.9 \\
\hline $75-79$ & 11.8 & 30.8 & 7.2 & 17.4 \\
\hline $80-84$ & 13.1 & 32.6 & 8.4 & 19.2 \\
\hline $85+$ & 14.4 & 33.9 & 8.4 & 20.7 \\
\hline \multicolumn{5}{|c|}{ Divorced or separated } \\
\hline $60-64$ & 13.8 & 28.2 & 9.0 & 18.6 \\
\hline $65-69$ & 13.0 & 26.8 & 8.6 & 17.1 \\
\hline $70-74$ & 13.4 & 28.0 & 9.4 & 17.2 \\
\hline $75-79$ & 13.9 & 29.2 & 8.9 & 18.0 \\
\hline $80-84$ & 12.9 & 29.6 & 9.7 & 19.3 \\
\hline $85+$ & 15.1 & 30.6 & 10.3 & 20.3 \\
\hline
\end{tabular}




\begin{tabular}{|c|c|c|c|c|}
\hline FEMALES & Toilet & Bath & Water supply & Hot water \\
\hline \multicolumn{5}{|l|}{ Never married } \\
\hline $60-64$ & 9.8 & 18.3 & 6.1 & 12.2 \\
\hline $65-69$ & 9.7 & 19.9 & 6.5 & 12.8 \\
\hline $70-74$ & 10.7 & 20.9 & 7.1 & 14.1 \\
\hline $75-79$ & 10.8 & 20.7 & 6.6 & 13.7 \\
\hline $80-84$ & 11.2 & 22.2 & 6.5 & 14.1 \\
\hline $85+$ & 13.2 & 25.3 & 6.2 & 15.8 \\
\hline \multicolumn{5}{|l|}{ Married } \\
\hline $60-64$ & 6.7 & 23.2 & 3.9 & 10.4 \\
\hline $65-69$ & 7.9 & 25.6 & 4.8 & 12.5 \\
\hline $70-74$ & 8.4 & 27.3 & 5.2 & 13.6 \\
\hline $75-79$ & 9.4 & 29.6 & 5.8 & 15.3 \\
\hline $80-84$ & 10.2 & 30.7 & 6.7 & 16.4 \\
\hline $85+$ & 11.8 & 32.0 & 6.6 & 19.1 \\
\hline \multicolumn{5}{|l|}{ Widowed } \\
\hline $60-64$ & 8.0 & 21.4 & 5.0 & 11.8 \\
\hline $65-69$ & 9.1 & 23.1 & 5.7 & 13.2 \\
\hline $70-74$ & 9.7 & 24.2 & 6.1 & 14.3 \\
\hline $75-79$ & 10.1 & 25.1 & 6.3 & 14.8 \\
\hline $80-84$ & 10.9 & 26.1 & 6.4 & 15.7 \\
\hline $85+$ & 13.4 & 29.1 & 7.0 & 18.0 \\
\hline \multicolumn{5}{|c|}{ Divorced or separ. } \\
\hline $50-54$ & 3.6 & 11.0 & 2.3 & 5.8 \\
\hline $55-59$ & 4.6 & 12.4 & 3.0 & 7.1 \\
\hline $60-64$ & 4.9 & 13.2 & 3.1 & 7.7 \\
\hline $65-69$ & 5.7 & 14.7 & 3.9 & 8.2 \\
\hline $70-74$ & 6.3 & 15.7 & 4.0 & 9.1 \\
\hline $75-79$ & 6.9 & 17.4 & 4.2 & 9.5 \\
\hline $80-84$ & 7.8 & 18.8 & 3.4 & 10.6 \\
\hline $85+$ & 11.1 & 24.2 & 3.7 & 14.1 \\
\hline
\end{tabular}

enjoy the highest standards. For example, never married men have a greater tendency to live in dwellings that lack water supply and/or bathroom facilities, e.g. toilet and bath. On the other hand, women who are widowed, divorced, or never married enjoy a standard almost as high as married individuals.

\section{Some concluding remarks}

The contentment of elderly persons is highly dependent on their economic circumstances and their housing standards. For senior citizens, a sufficient income is undoubtedly a prerequisite for independence and personal activity. Those who feel that their economic situation is bad are also more likely to be dissatisfied with their lives. However, very few senior citizens consider their economic situation to be bad. The majority of pensioners report that while they must be thrifty, they are able to cope well with their 
pensions. Since the oldest persons generally do not receive full employment-based pension and sometimes only national pension, they tend to be the poorest in society. Nonetheless, the situation will change gradually in this decade when new old-age pensioners receive full employment-based pension.

In Finland, more often than in other EU-countries, the next most important prerequisite for feeling of security is good, decent housing (Ministry of Social Affairs and Health 1994). During recent decades, the standard of housing has improved by leaps and bounds. Now the majority of seniors live in more spacious housing than the average citizen. However, the standard for the oldest pensioners, especially men who never married, is noticeably lower than the average.

Household arrangements influence strongly the social security of senior citizens. Those who live with others can obviously receive help and support more easily than those who live alone and must rely on municipal services for seniors. The majority of senior persons who live with a family member most often coreside with a spouse. Very few live together with children, brothers, sisters and others. Although it is unusual to live with children, it is not uncommon to get assistance from a child or children living elsewhere. However, senior citizens mostly prefer to use municipal social services rather than seek assistance from children and relatives. Assistance from other family members is generally regarded as a complementary source of support.

The Finnish report and this article illustrate the situation in Finland during the late 1980s and early 1990s. As the changes in household composition are generally slow and the economic recession in the beginning of the decade acted as an effective brake on social development, the living arrangements of senior citizens could be supposed to have changed rather little since the beginning of the decade and consequently reflect rather well the current situation of living arrangements in Finland. However, a more comprehensive picture would have required more detailed information on the living arrangements of the aged than the standard tabulations used in the project now present.

\section{References}

EVA (Elinkeinoelämän valtuuskunta) 1989 . Työtä tarjolla, missä tekijät (Jobs in supply, where are the workers. Publications of the Council of Economic Organizations. Helsinki.

Kärkkäinen, Sirkka-Liisa. 1994. Mökistä taajamiin. Ikääntyvien asuinolot. 1950-luvulta 1990luvulle (From cottages to densely populated areas. The housing conditions of the senior citizens from the 1950s to the 1990s). In: 55+. Katsaus ikääntyvien elinoloihin (55+. An overview of the living conditions of the elderly persons), edited by Raija Sailas and Sirkku Mikkonen, pp. 95-115. Living conditions 1994:1. Statistics Finland, Helsinki.

Melkas, Tuula. 1997. Muut ihmiset ikääntyvien elämässä. Ikääntyvien sosiaaliset ympäristöt (The social surroundings of elderly persons). In: 55+. Katsaus ikääntyvien elinoloihin 
(55+. An overview of the living conditions of the aged), pp. 123-145. Living conditions 1994:1. Statistics Finland, Helsinki.

Ministry of Social Affairs and Health. 1994. Vanhusbarometri 1994 ( The old-age barometer 1994). Ministry of Social Affairs and Health. Helsinki.

Puhakka, Aune. 1988. Project regarding the impact of social security benefits. Pensioner household's livelihood in 1985. Ministry of Social Affairs and Health, Planning Department. Publications 6/1988. Ministry of Social Affairs and Health. Helsinki.

Sailas, Raija. 1997. Ansioeläkkeistä toimentulon turva. Ikääntyvien tulojen rakenne vuosina 1966-1990 (Employees' pension, the security of livelihood. The income structure of the aged in 1966-1990). In: 55+. Katsaus ikääntyvien elinoloihin (55+. An overview of the living conditions of the aged), edited by Raija Sailas and Sirkku Mikkonen, pp. 69-82. Living conditions 1994:1. Statistics Finland, Helsinki.

Statistical Yearbook of Pensioners in Finland 1995. 1996. The Central Pension Security Institute and the Social Insurance Institute. Helsinki.

Tennilä, Liisa. 1997. Viisikymmentä ja risat (Fifty and over). In: 55+. Katsaus ikääntyvien elinoloihin (55+. An overview of the living conditions of the aged), edited by Raija Sailas and Sirkku Mikkonen, pp. 83-94. Living conditions 1994:1. Statistics Finland, Helsinki. 